\title{
REPRESENTATION IN THE LEGISLATURES OF THE NORTH CENTRAL STATES.
}

For the grouping of states adopted in this paper the readiest justification is to be found in the fact that they form one compact and comparatively homogeneous section. But other and weightier considerations confirm the propriety of the choice which has been made.

In the first place, these states all belong to the middle period of our constitutional development. It is true that in the interval between the admission of the first and of the last to the Union two generations passed away. Nevertheless, when Kentucky entered the Union, the "critical period" was already at an end, the federal government was in working order, and her sister commonwealths could furnish her, not paper constitutions merely, but the record of many years in the practical carrying on of government. At the other extreme, Nebraska, the youngest of these states, entered upon statehood at the close of the civil war, a full generation ago, long before the days of " omnibus " constitutions like those of her younger neighbors. While it is true that much of the law in regard to representation has been modified at irregular intervals by constitutional amendments, still the changes have been slight. These states have had to undergo no violent reconstruction, nor have they caught the radicalism of some of the younger commonwealths.

An added interest attaches to this grouping from the familiar fact that the settlement of the Mississippi basin has proceeded along parallels of latitude. The systems of representation introduced in the North Central states were the institutions which the sons of New England and of her neighbors found suited to their political life in the midst of a new environment; the modifications are those which new [405] 
occasions have taught men whose schooling in government had been upon the Atlantic seaboard.

I.

Who are represented? or rather, who may vote in the choice of legislators?

Although the suffrage law of these states is for the most part conservative, an occasional provision bespeaks the earlier frontier environment. Five have been so eager to attract settlers who should develop the country that they have granted the voter's privilege to an alien after he has resided in the state a few months and has declared his intention to become a citizen. ${ }^{1}$ The tendency in the more recently revised constitutions of the older states is to take the ground insisted upon by a sound political science, viz.: that completed citizenship of the United States should be a condition precedent to the grant of the suffrage. ${ }^{2}$ Wisconsin, however, in an amendment so late as 1882 , still retains this overenthusiastic welcome to immigrants, with the result that in forty-one out of the seventy-one counties a considerable majority of the voters are of foreign birth. ${ }^{3}$ Another reminder of the frontier environment in which some of these constitutions were framed is to be found in the specific provisions which have been made in regard to Indian citizenship and suffrage. Michigan and Wisconsin grant a vote to Indians not in the tribal relation; Minnesota admits to the suffrage persons of mixed white and Indian blood, who have adopted the customs and habits of civilization, and also pureblooded Indians who, upon examination before any district court of the state, shall prove that they have adopted the language, habits and customs of civilization, and shall be

\footnotetext{
'Indiana, Wisconsin, Missouri, Kansas, and Nebraska. Missouri, however encourages the completion of naturalization by insisting that the declaration of intention must have been made not less than one not more than five years before the alien offers to vote.

2 E. g. Illinois, 1870; Michigan, 1894; Minnesota, 1896 .

'See Table, Wisconsin Manual, 1899, p. 394.
} 
pronounced by the court capable of enjoying the rights of citizenship within the state.' There are, of course, the usual disqualifications of persons under guardianship or convicted of crime; many of the states specifically remove the disqualification in case of pardon or "restoration to civil rights." Bribery and the embezzling of public funds are sometimes singled out as special disqualifications. Indiana disqualifies United States soldiers, sailors and marines. Michigan shuts out all duelists and their accessories, while Kansas, in clauses which recall the troublous times which saw the birth of her constitution, disqualifies rebels not restored to citizenship and men dishonorably discharged from the United States service.

\section{II.}

\section{What is the basis of representation?}

A glance at the diverse ratios of senate to house membership in the legislatures of the North Atlantic states in but few instances suggests any theorizing on the part of the constitution-makers as to the normal size of legislative bodies, or as to the relative numbers in the two chambers. In most of those states, towns and counties had had a corporate existence before the constitutions were framed, and hence seemed entitled to recognition as separate political units. But when once the Alleghanies are passed, the restriction imposed by ante-constitutional conditions disappear; it is recognized that every local unit is not merely subject to, but is also the creature of the state constitution. The membership column in the accompanying table shows that in these states, with but few exceptions, theory and the spell of round numbers have been at work, asserting some normal limit to the membership in each house, and some normal ratio between the two.

1 Const. Art. vii, Sec. $\mathrm{r}$. The number of Indians and half-breeds entitled to vote is computed at 1342 . Minnesota Manual, 1899 , p. 548.

[407] 
Between the numbers of the two houses the favorite ratio is that of one to three. Missouri alone adopts a smaller one; in Indiana and Iowa the legislatures are of exactly the same numbers, and there are twice as many representatives as senators. Minnesota gives herself the largest senate of any state in the Union both absolutely and relatively to the membership of the lower house.

Nearly all of the constitutions fix the number of the members in each house, either by hard and fast limits, or by establishing maxima, which in every instance have been already reached. In six of the states the maximum for the house is roo, while in the others the range is only from 99 to 153 .

In most instances it is insisted that senators shall be chosen from single-member districts, regardful of county lines so far as is practicable in securing districts of approximately equal population within a compact and contiguous territory. Three states require that no county shall be divided in the formation of senatorial districts with the result that in their most populous counties several senators are chosen on a general ticket. In Ohio the constitution fixes the senatorial ratio as one thirty-fifth of the population of the state, and forthwith establishes for all time the bounds of thirty-three senatorial districts; a highly artificial and complicated method is then prescribed for allotting additional members; ${ }^{2}$ as a result in the legislature of 1899 there were thirty-six senators. With these rare and uninteresting exceptions the rule holds true, that in all twelve of the states each senator sits for his own private bailiwick.

In the lower houses there is less of this dreary but intelligible monotony in representation; each state has devised a system of its own. Still there is a marked tendency toward narrowing the constituency as much as possible. Wisconsin and Kentucky expressly require that the members shall

Indiana. Iowa and Nebraska.

- Constitution, Article XI. 
be chosen one from each district. In practice five other states approach this system closely, although not avowing it frank!y in their constitutions. Thus the Kansas constitution of forty years ago guarantees a member to each county which casts a vote of 250 , and makes provision for the representation of smaller counties; but according to recent legislation the state is now divided into I25 districts, each of which elects one representative. ${ }^{1}$ Next in order of simplicity stands Iowa, whose roo members are chosen from ninety-one districts. Four districts include two counties, and one district includes three; with these exceptions counties and districts are coincident. Michigan accepts the principle of choice by single districts; townships or cities, however, whose population entitles them to more than one representative, are not divided but make their choice by general ticket. Three members are secured to the Upper Peninsula, and special concessions are made to certain counties. Accordingly in the election of 1898 each of eighty-five districts chose a single member, while three others chose two, three, and ten, respectively.

In both Ohio and Missouri the first step in a reapportionment is to get a ratio of representation by dividing the population of the state by a round number which bears no close relation to the number actually to be chosen. ${ }^{2}$ Ohio allots one member to every county having one-half of this ratio, and then assigns additional members to the more populous counties according to a complicated schedule. What results is virtually county representation. In the legislature of I 899 five representatives came from districts each comprising two counties, while sixty-eight counties sent one member each; in only ten counties was a larger number elected. ${ }^{3}$ In Missouri one representative is given to every county containing one ratio or less; additional members are allotted

1 General Statutes, 1897 , Vol. i, p. 144 .

8100 in Ohio; 200 in Missouri.

8 Seven elected two each; one, three; one, nine; and one, ten. 
according to a diminishing schedule. Iarge counties are divided into single-member districts which shall choose one of their own residents as representative; counties entitled to ten or more, however, must be divided into larger districts, each choosing from two to four members. This is virtually special legislation, for it applies only to St. Louis. The result is that 108 counties send each one member; four send two each; one, three; one, six, while the city of St. Louis sends fifteen.

Nebraska's constitution simply provides that after each enumeration the legislature shall apportion the representatives according to the number of inhabitants; on the basis of the census of I895, the Ioo representatives are distributed among sixty-seven districts, thirty-seven of which are individual counties. Forty-six of these districts send one member each; seventeen, two; two, three; one, five; and one, nine. In Indiana after the state census in every sixth year the representatives must be apportioned among the several counties according to the number of male inhabitants. Accordingly fifty-one counties elect one representative each; seven elect two each; one, three; and one, seven. Contiguous counties having a surplus over the ratio are combined and from them a joint representative is selected; as many as five counties are sometimes brought together in this way; in the legislature of 1899 exactly a fourth of the membership were such joint representatives.

Illinois and Minnesota introduce an instructive novelty in making a single apportionment serve for the members of both houses of the legislature. Minnesota is the less systematic; comparatively little attempt seems to be made to secure proportionality to population in her sixty-three districts to each of which is allotted one senator. The compensation comes here, as in Congress, in the lower house, whose members are apportioned among the several districts in numbers varying from one to four. The Illinois practice is simpler. The state is divided into fifty-one senatorial dis[4IO] 
tricts of as nearly the same population as practicable. From each of these same districts there are elected three representatives.

\section{III.}

\section{How are the Legislatures elccted?}

In contrast with the North Atlantic states those now under discussion have reached uniformity upon many points. In all of them both the elections and the regular sessions of the legislature are biennial, although Ohio's "adjourned sessions" practically amount to annual meetings. In all of these states except four ${ }^{1}$ the senator's term is four years, and in all these states having the longer senatorial term except Minnesota and Kansas the renewal of the senate is gradual, one-half going out of office every two years. ${ }^{2}$

In five of the states there is no limit upon the length of the session. ${ }^{3}$ Three fix a definite limit in the constitution. ${ }^{4}$ The other four limit the sessions indirectly through shutting off the pay. Thus, however long Kansas legislators may loiter over their work, they get wages for only thirty days in a regular, and eighteen in a special session. Missouri draws the line at seventy days, but mercifully allows her legislators one dollar a day until the end of their sitting, if they choose to transgress this limit. Nebraska pays for sixty days in the regular session, but for not more than one hundred days in the entire term. Moreover, she insists that no curtailed performance shall be palmed off on her: an amendment of 1885 requires that " each regular session shall

1 Ohio, Michigan, Nebraska and Tennessee.

I In the Minnesota Constitution (Art. iv, Sec. 24) gradual renewal was provided for until the apportionment year. As to what should be the permanent rule, the wording of the constitution was unfortunately ambiguous. In accordance with the opinion of the attorney general (August 1I, 1892), the entire membership of the Senate is now renewed every four years.

Ohio, Illinois, Michigan, Wisconsin and Iowa.

Indiana, sixty-one days; Minnesota, ninety legisiative days; Kentucky, sixty days excluding Sundays and holidays. 
be not less than sixty days." Other states have not found it necessary to impose constitutional checks upon their legislators going home too early.

The practically universal choice of senators from single districts makes their election simply the determining which of several candidates shall win the one available seat. Indeed, in the elections which constituted the senates of 1899 it would seem to be the fact that in all eleven of the states there were but seven ${ }^{1}$ instances in which a given constituency had more than one senator to elect. In all but one of these the result was a solid delegation for the victorious party.

In the lower house, too, the marked tendency toward election by single-member districts robs the process of any especial interest. Several points, however, demand attention. In the first place, it is to be noted that the reluctance to divide a county in forming a representative district thrusts into a state eighty per cent. of whose representatives are chosen singly, the anomaly of one district choosing ten members on a general ticket. ${ }^{2}$ It may be questioned whether this is not over-straining a general ticket, and whether Missouri's provision as to the division of populous counties into large districts for the election of several members might not well be followed elsewhere. Indiana's method of choosing joint representatives from adjoining counties having fractional surpluses over the ratio has much to commend it; the field from which candidates are chosen is broadened, and the joint representative is in a position to look at questions from the general rather than from the purely local standpoint.

But by far the most interesting feature in the electoral system of these states is the introduction of cumulative, or

1 Five districts in Ohio, and one county each in Indiana and Nebraska.

2 In Michigan, District $I$, of Kent County, chose three; District I, of Saginaw County, two; District I, of Wayne County, ten. The first and last were solid delegations. Occasional use of the general ticket had to be made in Ohio, Indiana, Missouri, Nebraska, and Tennessee. 
"free" voting in Illinois. Here, as has been said, a single apportionment affords the basis for elections to both houses. In each of the fifty-one districts the constitution of 1870 provides that " each voter may cast as many votes for one candidate as there are representatives to be elected, or may distribute the same, or equal parts thereof, among the candidates as he shall see fit, and the candidates highest in votes shall be declared elected." Although this was much of a novelty in American political methods, its workings are very simple. How climulative voting affects both the choice of candidates and the resulting party representation will be the subject of later discusston.

In both the amount and the manner of payment the practice of the states varies. Four pay salaries, ranging from $\$ 500$ to $\$ I, 000$, for the regular session; the others pay day wages, Michigan and Kansas rating their legislators' services at $\$ 3.00$ a day, while Indiana pays $\$ 6.00$. All the states pay a mileage, ranging from ten to fifteen cents, and usually expressly limited to the distance the members shall " travel in going to and returning from the place of meeting of the legislature, on the most usual route." The Michigan constitution warrants an additional daily allowance of not more than two dollars to the members from the Upper Peninsula. ${ }^{2}$ All other perquisities are expressly prohibited in Ohio, Indiana, Wisconsin and Nebraska. Four states on the other hand make an allowance of from five to fifty

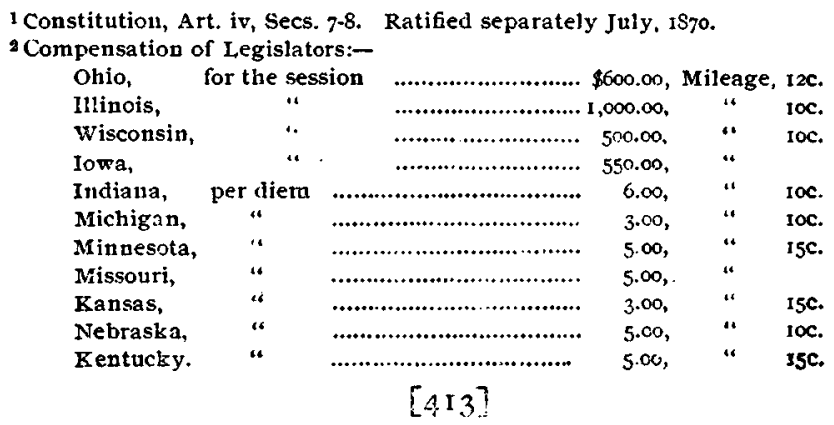




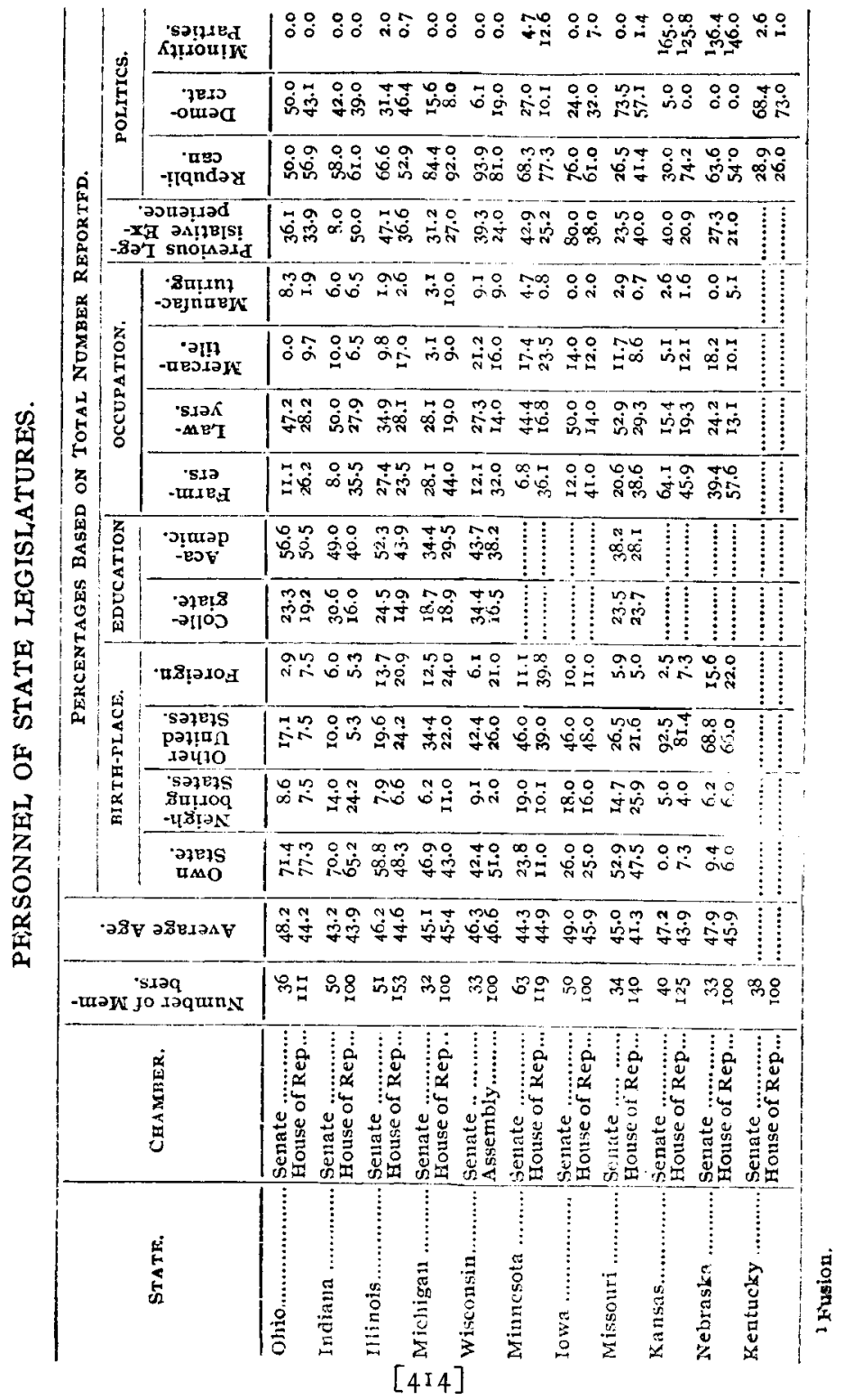


dollars for each member's postage, stationery and newspapers. ${ }^{1}$

IV.

Who are the Legislators?

The first step toward the answering of this question may be taken by noting the qualification which the constitutions exact of members. It may be taken for granted, even where not expressly stated, that the ordinary qualifications for electors must be possessed also by those who are to be given office. Wisconsin, Kansas and Nebraska still allow an alien to make laws for citizens. Indiana and Missouri, on the other hand, although granting the suffrage upon the declaration of the voter's intention to become a citizen, insist that all members of the legislature shall have completed their citizenship before entering upon their office.

Three states require that their senators shall have reached the age of thirty; ${ }^{2}$ three fix the limit at twenty-five. ${ }^{3}$ Missouri and Kentucky make twenty-four the minimum age of representatives. In all other instances, both in house and in senate, twenty-one is accepted.

Michigan and Kansas make no special qualification of previous residence. Every other state requires of senators a previous residence within the state of from one to six years, Kentucky being the most conservative. With but two exceptions this qualification is uniform in each state for the members of both houses. Kentuicky lowers the limit from six to two years for members of the lower house; Missouri, from three to two. With the exception of Wisconsin these states require that the legislator shall have been resident in his district immediately previous to his

1 Inlinois, \$50. Michigan, \$5. Kansas, statienery, and \$10 for postage. Missouri, \$30,

2 Missouri, Kentucky and Tennessee.

Indiana, Illinois nnd Iowa. 
election for a term varying from sixty days in lowa to two years in Illinois, the prevalent term being one year. Missouri's insistence that during that time the would-be legislator shall have paid a state and county tax is the one approach to a property qualification. Persons holding any other office of trust or profit under the state or national governments are everywhere disqualified. In a few instances removal from the district during service is stated to be tantamount to vacating the seat. Bribery and other corrupt practices are singled out for especial condemnation. Failure to account for public funds is listed by several states, and Nebraska disqualifies anyone "interested in a contract with, or having an unadjusted claim against the state." In the Kentucky oath of office aside from the pledge of loyalty to the constitution, and the faithful performance of official duties, the legislator swears that he has never taken part in a duel, nor in any way given aid or encouragement to duelists. Four other states have deemed a similar provision necessary. ${ }^{1}$

But no lengthening of the lists of constitutional qualifications will give much notion of the real personnel of legislatures, for we are concerned not with the thousands who possess all these qualifications, but with the tens who actually secure an election. This sorting out of the few from the many depends upon the interplay of a vast number of political forces, often peculiar to the locality, and the result can be conclusively estimated only after close personal contact with and observation of the various legislatures. Yet the several state manuals present material for some interesting comparisons. The average age of legislators seems to be much the same, the country over. In general the upper house maintains its appropriate seniority by a few years, but the difference is nowhere marked, and in several instances the order is reversed. On the whole, legislative service is devolved on men of ripe years; even Nebraska

'Indiana, Iowa, Kansas and Teunessee.

[4I6] 
shows little tendency to entrust her own law-making to boy orators. ${ }^{1}$

In the nativity of members the legislatures now under discussion present striking contrasts to those of the North Atlantic states, and indeed the contrasts are hardly less remarkable between the states of the present group. Ohio is even more conservative than Massachusetts in committing law-making to her own sons. In the Kansas legistature, on the other hand, only nine per cent of the representatives and not one of the senators can claim Kansas as his native state. The proportion of those who come from neighboring states is surprisingly small, especially in comparison with those born in remoter parts of the Union. That the settlement of the West has been by zones, and that the settlers have come, not from the adjoining states, but from those two or three removed to the eastward, are familiar facts to which the biographies of these legislators bear striking witness. Far in the lead of the other states in furnishing lawmakers to her neighbors stands Ohio, followed at a goodly distance by New York. This ascendency might raise the question whether the Ohioans are exceptionally migratory, or whether they are more clever politicians than others.

In but two of the legislative chambers of the North Atlantic states does the percentage of the foreign-born exceed eight, while that of those native to the given state never falls below sixty-one. In the present group these proportions are greatly changed. Strong contrasts in this regard are presented even between adjoining states of similar history, as between Kansas and Nebraska, in the former of which the representation of the foreign-born is inconsiderable. But it is in Michigan, Wisconsin, and above all in Minnesota that the immigrant has come to his own, and his own have sent him to the legislature. To what an extent European nationalities have colonized among us is evidenced

1 of the seventy-one whose ages were recorded only six of the Nebraska representatives were less than thirty-five years of age. 
by the fact that in a state admitted to the Union nearly half a century ago forty per cent. of the representatives should be of foreign birth, Norway alone having sent her more lawmakers than those born within her own borders. ${ }^{1}$

As regards education a thorough-going comparison is impossible. The fact that all but one of these commonwealths maintains as the the crown of its public school system a state university, in which education entails little direct cost upon a young man or his parents, makes the situation quite different from that in the states east of the Alleghanies. Several states of this group are proverbial for their profuse supply of "colleges." It is, however, a familiar paradox that the community most liberally provided with colleges is not necessarily the one most richly served by them. Heterogeneous as the data concerning education are, the attempt has been made to adhere as closely as possible to a uniform system of classification in all the states. ${ }^{2}$ In general, the senates contain the larger proportion of men of college training; the percentages in Wisconsin and in Ohio are on the whole the most remarkable.

In the callings of senators and of representatives there is less of variety, or, rather, less of evenness of distribution than in the eastern states. In but one of the chambers does one member in tein come from the mantufacturing class. Mercantile pursuits have furnished a much larger proportion; yet out of the twenty-four legislative bodies it is only in two that it rises as high as one in five, whereas in nine of the North Atlantic states this proportion is exceeded in one house or the other, often in both. ${ }^{8}$ It is from the ranks of farmers and lawyers that the legislators are mainly recruited,-indeed, with the exception of Wisconsin, there is

1 of the zrinnesota represesentatives thirteen were born in that state, fourteen in Norway, eight in Sweden, eight in Germany, and nine in Canada. In Michigan's quota of foreign-born legislators the largest element comes from Canada; in Wisconsin's, from Germany and the United Kingdom.

2 For a discussion of the available educational data, and of their classification, see ANnals, March, 1900, p. 78 .

8 Exceeded in fourteen out of the twenty-two. 
no legislature in which these two callings do not furnish considerable more than half the members. With the exception of Illinois and Kansas, ${ }^{1}$ the farmers are far stronger in the house than in the senate, while in the upper house as a rule the lawyers outvote the farmers, sometimes seven to one, as in Minnesota. In the Ohio legislature it is remarkable that more than a third of the representatives at some stage in their career have been school teachers. In several states bankers seem to be farorite candidates; in Iowa they constituted twelve per cent. of the senate and eleven per cent. of the house, proportions far larger than the writer has yet observed in any eastern state.

The senate usually draws to itself the greater proportion of men of legislative experience. In the Iowa senate of 1898 four out of five of the members had seen previous service. While even in this instance the proportion is not so high as in several North Atlantic states, it is interesting to observe that the lower house holds its own in this matter of legislative experience far better than in the East. The Indiana and Missouri figures present unaccountable variations from the normal in this matter. On the whole, Kansas and $\mathrm{Ne}$ braska seem to have the least regard for seasoned legislative timber. ${ }^{2}$

But the mere possession of exceptional aptitudes for legislative work by no means makes it likely that a man will therefore find his way into the legislature. He must first have proved himself an available candidate. The biographical sketches afford an occasional hint as to things that may have made for availability. Not without significance is the large number of war veterans who have seats in the legisla-

1 The reversal in the Kansas legislature of the proportions prevalent elsewhere is doubtless due to the fact that the eiection of 1898 , which constituted the house, proved disastrous to the Populist party; as the senate's term is four years, only four senators were to be chosen, to fll vacancies. The data in the senate column, therefore, for the most part reflect political conditions and party preferences of two years earlier than the data in the house column.

2 Kansas, however, has one representative who has served for eight successive terms. Ohio and Towa have each a man with a record of eighteen years.

[4 I9] 
tures. They constitute 23 per cent. of the Kansas legislature; in the Missouri legislature 14 per cent. of the members had been in the active service of the Union, while 6 per cent. were Confederate veterans. The long lists of orders appended to the names of many of the members suggests that here, too, may be found evidence of a clientele which has proved serviceable to many an aspirant for office. Thus in the Illinois house two out of every three members belong to some secret order, and two out of every five are Masons. These proportions are probably not exceptional.

$\mathrm{V}$.

To what extent does each state's system of representation make the political complexion of the legislature vary from that of the body of the woters?

So many varying forces are here involved that no precise answer to our question is possible. Yet the loyalty with which the great majority of voters cast the straight ticket of the party, no matter what office is to be filled, makes it possible to institute some suggestive comparisons. The accompanying table presents the percentages of the aggregate vote cast for each party's candidate for the highest state officer chosen in 1898 , and the proportionate influence which each party secured in the legislature chosen at the same time. At the best this test is somewhat misleading, ${ }^{1}$ and for several reasons it is less satisfactory in dealing with the present group than in the case of the states last under discussion. In the first place, in only half of the states was a governor chosen; in the other instances the vote for some other state officer has to serve for our comparison." Again, only four

\footnotetext{
1 Some of the qualifications which must be made in drawing conclusions from such a comparison as discussed in ANNALS, March, Ig0o, p. 82.

2 Governor, in Michigan, Wisconsin, Minnesota, Kansas and Nebraska. Secretary of State, in Ohio, Indiana and Yowa. State Treasurer in Illinois. Judge of Supreme Court in Missouri. Clerk of Court of Appeals in Kentucky. Were not the election of the highest officer on the ticket always made a test of party strength, this variety would be fatal to our comparison. In the present condition of state politics, however, it is practically immaterial.
} 
of the senates were entirely renewed in 1898 ; in seven, onehalf of the senators were newly chosen, while in Kansas but four vacancies were filled. Hence the comparison of party strength in the two houses becomes less conclusive. Finally, party lines especially in Kansas and Nebraska in recent years have been so blurred that the official manuals either use party designations inconsistently in the lists of candidates or else omit them altogether. Yet although the data in the table can be accepted only as a rough approximation to the answer to our query, they have not a little significance.

\section{Party Votes Compared with Party Representation.}

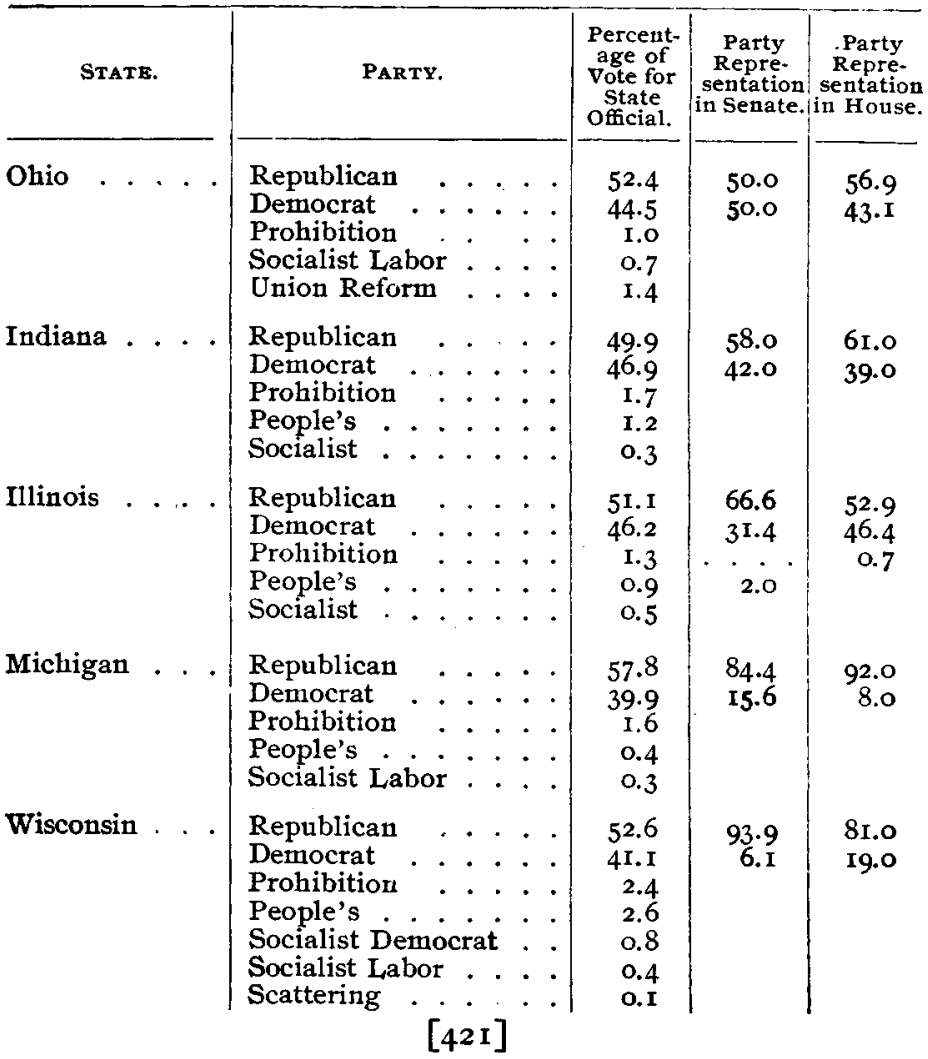


Annals of the American Academy.

\begin{tabular}{|c|c|c|c|c|c|c|c|}
\hline STATE & & & PARTY. & & $\begin{array}{l}\text { Percent- } \\
\text { age of } \\
\text { Vote for } \\
\text { State } \\
\text { Official. }\end{array}$ & $\begin{array}{c}\text { Party } \\
\text { Repre- } \\
\text { sentation } \\
\text { in Senate. }\end{array}$ & $\begin{array}{l}\text { Party } \\
\text { Repre- } \\
\text { sentation } \\
\text { in House. }\end{array}$ \\
\hline Minnesota & & & $\begin{array}{l}\text { Republican } \\
\text { Democrat-Populist } \\
\text { Prohibition } \\
\text { Socialist Labor } \\
\text { Mid. Road Populist }\end{array}$ & 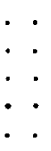 & $\begin{array}{r}44.3 \\
52.3 \\
2.1 \\
0.6 \\
0.7\end{array}$ & $\begin{array}{r}68.3 \\
27.0 \\
1.6 \\
3.2\end{array}$ & $\begin{array}{l}77.3 \\
15.1 \\
0.8 \\
6.7\end{array}$ \\
\hline Iowa & . & & 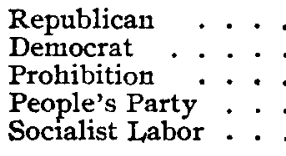 & 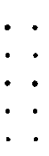 & $\begin{array}{r}56.1 \\
41.0 \\
1.8 \\
0.8 \\
0.3\end{array}$ & $\begin{array}{l}76.0 \\
24.0 \\
. \\
.\end{array}$ & $\begin{array}{l}61.0 \\
32.0 \\
3.0 \\
4.0\end{array}$ \\
\hline Missouri . & $\cdot$ & - . & $\begin{array}{l}\text { Republican } \\
\text { Democrat } \\
\text { Prohibition } \\
\text { People's Party : } \\
\text { Socialist Democrat } \\
\text { Socialist Labor . . }\end{array}$ & $\begin{array}{l}. \\
: \\
: \\
: \\
: \\
.\end{array}$ & $\begin{array}{l}45.9 \\
51.3 \\
0.5 \\
1.8 \\
0.3 \\
0.2\end{array}$ & $\begin{array}{l}26.5 \\
73.5\end{array}$ & $\begin{array}{l}4 I .4 \\
57.1 \\
I .4\end{array}$ \\
\hline Kansas & - & - . & 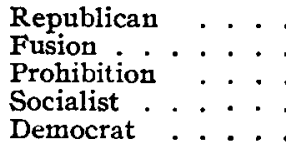 & 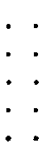 & $\begin{array}{r}51.8 \\
46.6 \\
1.4 \\
0.2\end{array}$ & $\begin{array}{l}30.0 \\
65.0 \\
5.0\end{array}$ & $\begin{array}{l}74.2 \\
25.8\end{array}$ \\
\hline Nebraska & & . . & $\begin{array}{l}\text { Republican } \\
\text { Democrat (Fusion) } \\
\text { Prohibition : } \\
\text { Socialist Labor : }\end{array}$ & 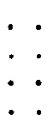 & $\begin{array}{r}48.8 \\
50.2 \\
0.9 \\
0.1\end{array}$ & $\begin{array}{l}63.6 \\
36.4\end{array}$ & $\begin{array}{l}54.0 \\
46.0\end{array}$ \\
\hline Kentucky & & - & $\begin{array}{l}\text { Republican } \\
\text { Democrat } . . \\
\text { Sound Money Democ } \\
\text { Populist . . . . . }\end{array}$ & $\begin{array}{l}\dot{.} \\
\dot{\text { crat }} \\
\dot{\cdot} .\end{array}$ & $\begin{array}{r}45.4 \\
50.2 \\
2.6 \\
1.9\end{array}$ & $\begin{array}{r}28.9 \\
68.4 \\
2.6\end{array}$ & $\begin{array}{l}26.0 \\
73.0\end{array}$ \\
\hline
\end{tabular}

The wide variations are in many instances to be accounted for by the rigid adherence to the one-member districts. The only state which has attempted to secure some degree of proportionality in representation is Illinois, where for thirty years the cumulative vote has been in practical operation in the election of members of the lower house. Whether this or any form of proportional representation is desirable or not, is a debatable question. That it is here effective in [422] 
giving a voice to the minority is evident from the fact that in the house elected in 1898 the delegation from every one of the fifty-one districts stood 2:I. In but four districts is there any possibility that the minority, owing to their opponents having " plumped" too heavily on the more popular candidate, have been enabled to elect two out of the three representatives. ${ }^{1}$ How much more accurately this method of voting makes the legislature reflect the views of the electors than does the ordinary method may be seen by comparing the house figures with those for the senate, all of whose members were elected on the same day by majority vote in single districts.

VI.

\section{To what extent is the representative system elastic?}

No section of the United States is more lavishly endowed by nature, none is more rich in opportunity than the North Central States. Ten years ago they contained more than a third of the total population of the country, and, except in the newer West, nowhere else is the rate of increase so rapid. $^{2}$ Yet the redistribution of population is a no less striking phenomenon here than in the East. It is the urban population that makes the strides; the rural communities are falling behind, not relatively merely, but absolutely." Hence the representation which suits one time is speedily outgrown, and readjustment becomes necessary if political equity is to

\footnotetext{
1 These are Districts 6,9,40 and 49. In two the Democrats won; in two, the Republicans, so that accidents were equally divided.

2 U. S. Census, 1890 , Population, Part I, p. xiii, and p. 2.

" "The Doom of the Small Town," H. G. Fletcher, Forum, April, 1895. Fixcluding Cook County, Illinois, and counties whose boundaries had been so changed as to make comparison impossible, it is shown that atthough the states (Ohio, Indiana, Mllinois, Michigan and Iowa) were gaining in population at rates varying from Io to 24.3 per cent. in the previous decade, of the townships 144 were stationary, 3,003 gained while 3,144 lost. Figures in regard to each state are there presented which fully substantiz te the above statement.
} 
be realized. The easiest way in which to effect a readjustment, of course, is to grant additional members to the communities which have gained in population. But the constitution of every one of these states bears witness to a conviction that as legislative bodies grow larger there comes a point beyond which there is a diminishing return in legislative efficiency. Under the spell of round numbers limits have been set, sometimes far in advance of the membership at the time of the framing of the constitution; in every instance, however, the tide of democracy has already brought the actual representation up to these maxima. Reliance is therefore placed upon frequent reapportionments. In every state they occur not less often than once in a decade; in five, they are made every five years; in Indiana, every sixth year; the more frequent apportionments are found in the younger states.

Throughout this section it is so clearly recognized that the county, the township, the municipality are all not only subsequent to the state, but also the creatures of the state, that party spirit has found in history no cloak for an attempt to perpetuate a rotten borough system, as in Vermont and Connecticut. Although several constitutions provide that no county shall be divided in the formation of districts, there is little prejudice against allotting additional representatives to the most populous, while sparsely settled counties are combined into single districts with the greatest freedom. Rigid adherence to election from single districts in Wisconsin, Kentucky and Kansas undoubtedly gives a somewhat disproportionate influence to the smaller communities. In minimizing the evils of the single-member system Indiana's joint representation gives excellent results.

No one of the states has sought to curb the increasing power of cities directly, by fixing a limit upon the number of legislators whom they may elect, as is done in New York and Riode Island. Whatever check is applied to the growth of city influence comes from the use of the diminishing $[424]$ 
ratio, which has been introduced in three states. In Ohio ${ }^{1}$ and Michigan ${ }^{2}$ its effect is not very marked; in Missouri, ${ }^{3}$ on the other hand, the influence of the state's one great city is held very sharply in check.

In contrast with the legislatures of the parent states, those of the present group present law-making bodies whose size has been fixed according to theoretical notions. The influence of cities in the representative body has as yet rarely been put under appreciable restraint. In the personnel of their legislatures most of these states have relied to a surprisingly large extent on others than their own sons, choosing farmers and lawyers by preference, and paying such devotion to rotation in office that little legislative experience is secured. In the apportionment of members no prescriptive right to a fixed representation is recognized as inhering in any local unit, but the attempt is made at frequent intervals to readjust district lines in such a way as to bring about substantial proportionality to population.

Worcester Polytechnic Institute.

George H. Haynes.

${ }^{1}$ Constitution of Ohio, Art. xi, Secs, 1-5: R. equals the population of the state divided by 100 ; one-half $R$. entitles a county to a representative; one and threefourths $R$. entitles a connty to two representatives; three $R$. entitles a county to three representatives; and thereafter each full $R$. gives a representative. Elaborate provision is also made that counties having a considerable fractional surplus over the $\mathbf{R}$. shall be allowed an additional member at a number of sessions during the decade proportional to the size of this fraction. This is analogous to the practice in New Hampshire.

2In Michigan two representatives are allowed to any county " having a ratio of representation and a fraction over, equal to a moiety of said ratio; and so on above that number, giving an additional member for each additional ratio." Constitution, Schedule, Sec. 22.

8In Missouri one representative is given to each county containing one ratio or less. R. equals the population of the state divided by 200 . Additional members are then allotted as follows: two and one-half $R$. entitles a county to two representatives; four $R$. entitles a county to three representatives; six $R$. entitles a county to four representatives; and thereafter two and one-half $R$. brings an additional member. According to the last census the population of Missouri makes $R$. equal 13.395. There are thirty-seven counties with less than one R., ranging up from

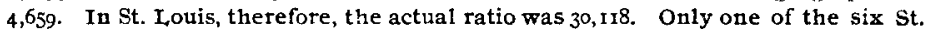
Louis districts elected a mixed delegation. 